\title{
Standards Process of Learning Implementation in SMP Harapan Ibu Banyuasin, Indonesia
}

\author{
Rizqi Dian Amanda \\ Universitas PGRI Palembang, Indonesia \\ Email: nandha.amanda@yahoo.com \\ Bukman Lian \\ Universitas PGRI Palembang, Indonesia \\ e-mail: drbukmanlian@univpgri-palembang.ac.id
}

\author{
Alhadi Yan Putra \\ Universitas PGRI Palembang, Indonesia \\ e-mail: alhadian.putra@univpgri-palembang.ac.id
}

Article History: Received on 4 November 2021, Revised on 22 January 2022

Published on 7 February 2022

\begin{abstract}
This study aimed at determining how does the standard process in English Learning at SMP Harapan Ibu Tanah Mas Banyuasin. This study was a qualitative using study case method. This study was done at SMP Harapan Ibu Tanah Mas Banyuasin with six respondents were the headmaster, assistant of the headmaster in curriculum, operator, administration staff, and two teachers of English. Data collection technique used in this study were interview, observation and documenting. The truthworthness in this study was using triangulation. The findings showed that (1) the implementation of standard process at SMP Harapan Ibu has done according to the national standart at the school which they still used the school based urriculum and curriculum of 2013; (2) the learning implementation has conveyed aaccording to the schedule of the school; (3) findings the differences implementation of using school based curriculum has been conveying in 7 and 8-1 class, and using curriculum of 2013 at 8-2, 9-1 and 9-2 class.
\end{abstract}

Keywords: Standard Process, Implementation of Learning, English Education

\section{A. Introduction}

Education is an important component in the development of a country's human resources. According to Kristiawan et al (2019), education is something that persuades a nation as a developer that it is vital and necessary to govern. Of course, it is also a cause to improve a nation's intellect. In reality, this educational interest has been proclaimed since the 1945 Constitution was drafted. Development in educational performance also includes instructors, in addition to becoming a teacher.

According to Lian (2018), a teacher requires an approach that can assist students lead complicated lives and avoid restricted understandings of race, place, ethnicity, culture, and history as an educator. According to Lydia et al (2019), an educator must not only understand their subject of study, but also master and be able to convey these knowledge and abilities to pupils. As a result, an educator, in the sense of giving information and developing abilities, requires a dominating norm that serves as a benchmark for the application of the national 
standard education process. This suggests that the teacher's presence and the manner in which he teaches are critical factors in student growth.

As a result, the presence of instructors, students, facilities and infrastructure, the educational environment, and the curriculum serve as a benchmark for the execution of the educational process and success in education in line with predefined criteria (Abdullah, 2016). Instruction cannot function without a curriculum since there are no guidelines or goals for the education offered. This is consistent with what Lewis (2011) and Hernawan \& Andriyani (2011) stated, namely that the curriculum is all school attempts to motivate pupils to study, both in the classroom, in the school yard, and outside of school. Because the curriculum ensures that instruction in schools may be carried out until educational goals are met.

According to Munif (2015), a country's curriculum is prepared and constantly improved in order to improve education in the country. Similarly, in Indonesia, the curriculum is always being revised in order to strengthen the Indonesian education system. As a result, while developing a curriculum, it must be evaluated if the curriculum is truly capable of improving in all aspects of education.

The curriculum 2013 was established as part of an effort to reform the curriculum in Indonesia. According to an article on Liputan6.com (2019), the implementation of the curriculum 2013 began in 2013 at certain schools that were thought capable of running it as a pilot school for the implementation of the 2013 curriculum. Until 2014, the 2013 Curriculum was being implemented in practically every school. However, this implementation was still in 2014 and could only be carried out for one semester before returning to the former curriculum structure, namely the School Based Curriculum. However, in the meanwhile, the schools chosen as pilot sites continue to use the curriculum 2013 framework.

According to Sanjaya (2018), the curriculum 2013 focuses on students' understanding, skills/ability, and character education. Students are required to understand the material, be active in discussion activities and show presentations, and have a high polite attitude toward others. The Standards for the Primary and Secondary Education Process are contained in Regulation of the Minister of Education and Culture No. 22 of 2016, which states that the learning process is accompanied by a scientific approach that includes all observation or observation activities to formulate hypotheses or collect data. There are three learning models established in the Curriculum 2013, which is based on Regulation of the Minister of Education and Culture 22 of 2016 about Education Process Standards, including discovery learning, problem-based learning, and project-based learning (Sani, 2014).

Curriculum changes, of course, apply to all courses in all school systems, including English subjects. The goal of studying English is to master the four language abilities that everyone must acquire. An English teacher must be able to teach these four language abilities to students. Regardless of the curriculum established by the government, instructors are required to be able to teach and develop the four language skills that pupils will learn. This is similar to what Pranowo (2014) stated, that regardless of the form of the curriculum and the direction of the theory, language learning still entails four skills, namely listening, speaking, reading, and writing skills in both the field of language and written literature.

English teachers believe that learning English is essential for students' development of life skills, both in industry and in the business sector. This is consistent with Asmani (2009) 
Volume 3 (1) 2022

E-ISSN: 2723-6919 P-ISSN: 2746-0827

assertion that SMP provides students with life skills, including the development of English language abilities to assist their prevocational and vocational skills.

Learning management, via the use of many approaches and good concepts, is capable of better managing the classroom and learning environment, as well as increasing students' creativity and interest. According to Juano (2016), the key factor that is most sought in the implementation of education in schools is the success of the process of learning activities. As a result, each educational unit will develop learning plans, implement the learning process, and analyze learning results in order to enhance efficiency and activities to attain graduation competency.

As indicated in the preceding section, learning is a complicated process with several components (Setyosari, 2020). One of them is the Learning Implementation Plan, which entails constructing instructional materials that include teacher preparation prior to beginning learning. All educators are required to complete RPPs in order for the teaching-learning system to take place in an inspiring, interactive, challenging, efficient, comfortable, and motivating way for students to be active in order to provide space for creative actors, as well as independence equal to interests, talents, and physical development (Setyosari, 2020).

Based on the findings of the preliminary interview between the researcher and the principal of SMP Harapan Ibu Banyuasin (Samsudin, S.Pd, M.Pd. on December 13, 2020). He stated that there were a number of issues with the curriculum and standard implementation practices. And, in this day and age, all schools are supposed to use and apply the 2013 Curriculum, although in actuality, there are still instructors or educators that utilize the previous curriculum syllabus or lesson plans, namely the School Based Curriculum. As a result, we did research at SMP Harapan Ibu Banyuasin.

Based on the preliminary findings of the principal interview, the researcher wishes to investigate and improve the quality of student learning, particularly the English learning process at Harapan Ibu Banyuasin Middle School, which was delivered by each class teacher, under the research title "Standard Process of Learning Implementation in SMP Harapan Ibu Banyuasin, Indonesia".

\section{B. Methods}

This investigation will last three months, from July to September 2021. Researchers conduct research in stages, beginning with preparation for interview research, an initial survey of the location, determining the relevant literature review, beginning the arrangement of results seminars, conducting seminar results seminars, creating research instruments, collecting data, and analyzing the data. The principal, two English instructors, one TU staff member, one curriculum representative, and one school operator at SMP Harapan Ibu Banyuasin are the subjects of this study. The data sources utilized as studies in this research include all English instructors at SMP Harapan Ibu Banyuasin and staff participating in the standard learning process, the data sources for which will be gathered using data collecting techniques such as interviews, observation, and document analysis (Sugiyono, 2015; Pujaastawa, 2016; Kusumastuti and Khoiron, 2019). 


\section{Results and Discussion}

The procedure of studying English at SMP Harapan Ibu Banyuasin has been carried out in accordance with the educational process standards utilized by each instructor. The standard process utilized in the curriculum at SMP Harapan Ibu comprises a standard process that refers to the School Based Curriculum but has gradually been replaced by the curriculum 2013 . Because SMP Harapan Ibu is still located in rural sections of the community, some of the instructors still do not understand, this standard procedure is followed and recognize the significance of implementing the new curriculum that must be used with students during the learning process.

The delivery of the learning implementation process in Class 7 is in accordance with the curriculum content used, namely the School Based Curriculum 2006, but there are still some things that need to be improved, due to deviations from the standard process that has been planned differently than what is being implemented, as well as differences in media used by teachers. Due to learning activities that are not in accordance with the standards of the implementation process, the researchers observed if there were students in grade 7 who could not understand and required a good approach, guidance, and direction so that the teacher's implementation process did not become ambiguous.

We discovered the same phenomenon in grade 8, grade 8-1, namely the use of lesson plans and books/materials still utilizing the school-based curriculum that is still utilized by the instructor in question, pupils comprehend enough and can apply it in practice. We discovered that in grades $8-2$, the process of applying the learning was proceeding smoothly and in accordance with the standard method that had been established. This lesson still requires guidance, approach, and direction in order to attain the intended results in the learning process to the maximum extent possible and to be applicable in everyday life.

According to the findings in grade 9, including grades 9-1 and 9-2, the learning process activities were deemed good and in compliance with the standard processes in the curriculum that had been employed. Were the we made direct observations, we discovered that there were some students who did not pay attention to learning well with what the teacher had conveyed, as seen by the discontinuity of the response. students when asked by the teacher. There are still kids in the rear seat who are speaking and creating noise with their mates.

Based on the findings of the research in the learning implementation process at SMP Harapan Ibu Banyuasin, We concluded that the standard process implemented at SMP Harapan Ibu, particularly English learning, was going well and in accordance with the government's standards. This is demonstrated by the teacher's readiness prior to carrying out the learning process, particularly the preparation of a Learning Implementation Plan, as well as the preparation of resources, media, and techniques that will be utilized in the learning process.

Before accessing the core content, the instructor begins learning with introductory exercises like as greetings, reading prayers (particularly in the first hour), and doing a quick review both reviewing the prior material and providing clues to the material to be studied today. Then, according to the time allotment, each instructor enters the core of learning and concludes with an evaluation. Alternatively. In order to address the issues that arose at SMP Harapan Ibu Banyuasin, such as the fact that the curriculum 2013 had not yet been fully implemented, 
changes would be required so that the standard process implemented would be in accordance with the graduation standards set by the government.

Implementation in the process of learning English must be done on a constant basis. Each student's characteristics differ from one another. There are students that simply assimilate the teachings and immediately grasp the concepts of the lessons being taught, while others require more time and more extensive explanations to understand the lessons being taught. The instructor constantly gives opportunities for pupils to ask questions and discuss if they face challenges in the learning process that has been provided, based on the execution of the learning supplied. As a result, teachers must be able to adapt their programs to meet competence criteria and student graduation requirements based on current educational achievement (Maryati et al, 2021).

According to the research findings, there are various causes creating classroom instructors' difficulties in executing the English language learning process in compliance with national education standards, including 1) there are still teachers who utilize the School Based Curriculum. Because it is currently mandated by the Minister of Education and Culture for all educators in every education unit, particularly elementary and secondary schools, to use the 2013 curriculum as a reference for graduation standards; 2) The standard process used by the curriculum at SMP Harapan Ibu is still not optimal because some of its contents still contain the School Based Curriculum reference and are completely still in stages with the use of the Curriculum 2013; 3) Teachers at SMP Harapan Ibu still require guidance and direction on how important it is to implement process standards with the most recent curriculum in order to keep up with the progress of their students' graduation standards; 4) The achievement of learning outcomes for each student is varied and different as a result of the implementation of different process standards by the two teachers.

In essence, humans may become quality beings as a result of their education; education is what makes individuals a valuable resource for the advancement of a dignified nation. This is consistent with Agustiani (2015) viewpoint, which asserts that "education is an endeavor to increase one component of the quality of human resources." Since elementary school teachers, methods for increasing high-quality human resources have been used. Good and quality human resources will produce a strong nation, therefore growth in the field of education is extremely supportive of the achievement of a successful and quality living for the nation and the state (Maryati et al, 2021).

Given the importance of education in the production of human resources, enhancing educational quality must be done on a continuing basis. The challenge of tying education quality is inextricably linked to the problem of the learning process. In that context, English education must educate students to become citizens capable of using international languages and developing them into the international realm, in order to open new paths for this country's development and to demonstrate that Indonesia's human resources are of high quality, allowing it to compete in the world international domain (Masuri et al, 2022; Ernawati et al, 2022; Nuryani et al, 2021).

According to Juano (2016), the major goal of education in schools is to ensure the success of the learning process. As a result, approaches to increase today's students' achievement may be offered using the most recent learning methods that have been established and are always student-centered. In order to construct a student center system. With the diversity of a teacher's 
Volume 3 (1) 2022

E-ISSN: 2723-6919 P-ISSN: 2746-0827

talents as well as the various features of pupils in each area of the education unit, Regulation of the Minister of Education and Culture No. 65 of 2013, namely the Standards of the Learning Process, was created to develop a common view about the implementation of learning (Kusuma, 2018).

\section{Conclusion}

This study concluded that the standard implementation of the English learning process at Harapan Ibu Junior High School had been carried out in accordance with the standard process determined by the government, both from the implementation that referred to the Curriculum 2013 and the School Based Curriculum, which was still in effect at the school. The usage of the School Based Curriculum in learning English was discovered in grades 7 and 8-1, but the use of the curriculum 2013 was discovered in grades 8-2, 9-1, and 92.

\section{E. Acknowledgement}

Thank to Rector Universitas PGRI Palembang, Director of Postgraduate Program and Chief of Study Program Management of Education Universitas PGRI Palembang and friends who have supported us to do this valuable project.

\section{References}

Abdullah, R. (2016). Pembelajaran dalam Perspektif Kreativitas Guru Dalam Pemanfaatan Media Pembelajaran [Learning in the Perspective of Teacher Creativity in the Use of Learning Media]. Lantanida Jurnal, 4(1), 35-49.

Agustiani, R. (2015). Profil Pengetahuan Pendagogik Konten Mahasiswa Calon Guru Matematika dalam Melaksanakan Pembelajaran Dengan Pendekatan PMRI [Profile of Pedagogical Knowledge Content of Prospective Mathematics Teacher Students in Implementing Learning with the PMRI Approach]. Jurnal Pendidikan Matematika RAFA, 1(2), 288-305

Asmani, J. M. (2009). Manajemen Strategi Pendidikan Anak Usia Dini [Early Childhood Education Strategy Management]. Yogyakarta: Diva Press.

Ernawati, E., Harapan, E., \& Kesumawati, N. (2022). Improving the Quality of Learning in Primary Schools. Journal of Social Work and Science Education, 2(3), 269-274. https://doi.org/10.52690/jswse.v2i3.258

Hernawan, A. H., \& Andriyani, D. (2011). Hakikat Kurikulum dan Pembelajaran [The Nature of Curriculum and Learning]. Pengembangan Kurikulum dan Pembelajaran EKOP.

Juano, A. (2016). Pengaruh Pembelajaran Problem Posing Terhadap Kemampuan Berpikir Kritis Dan Komunikasi Matematis Siswa Kelas V SD [The Effect of Problem Posing Learning on Critical Thinking and Mathematical Communication Skills for Fifth Grade Elementary School Students]. Jurnal Prima Edukasia, 259-278.

Kristiawan, M., Yuniarsih, Y., Fitria, H., Refika N. (2019). Supervisi Pendidikan [Education Supervision]. Bandung: Alfabeta 
Kusuma, C. S. (2018). Integrasi Bahasa Inggris Dalam Proses Pembelajaran [Integration of English in the Learning Process]. Jurnal Efisiensi, 15(2), 43-50.

Kusumastuti, A., \& Khoiron, A. M. (2019). Metode Penelitian Kualitatif [Qualitative Research Methods]. Semarang: Lembaga Pendidikan Sukarno Presindo

Lewis. (2011). Kurikulum dan Pembelajaran Dalam Pembelajaran [Curriculum and Learning in Learning].

Lian, B. (2018). Pendidikan Global Sebagai Instrument Berbangsa dan Bernegara [Global Education as an Instrument of the Nation and the State]. Prosiding Seminar Nasional 21 Universitas PGRI.

Liputan6.com. (2019). Tujuan Kurikulum 2013 [Goals of Curriculum 2013]. https://www.liputan6.com/citizen6/read/3875318/tujuan-kurikulum-2013-di-balik-prokontra-penerapannya

Lydia, L., Fitria, H., \& Puspita, Y. (2021). Policy Implementation of Educational Quality Improvement Based on National Education Standard. Journal of Social Work and Science Education, 1(3), 221-233. https://doi.org/10.52690/jswse.v1i3.109

Maryati, S., Ahmad, S., \& Eddy, S. (2021). Management for Improving the Quality of Student Learning in Primary Schools. Journal of Social Work and Science Education, 1(3), 257265. https://doi.org/10.52690/jswse.v1i3.113

Masuri, M., Fitria, H., \& Mulyadi, M. (2022). Improving the Quality of Education in Public Primary School. Journal of Social Work and Science Education, 2(3), 259-263. https://doi.org/10.52690/jswse.v2i3.256

Munif, D. N. (2015). Implementasi Kurikulum 2013 Mata Pelajaran Bahasa Inggris di SMP Negeri 9 Madiun [Implementation of the 2013 Curriculum for English Subjects at SMP Negeri 9 Madiun]. An-Nuha, 284-297.

Nuryani, N., Harapan, E., \& Wardiah, D. (2021). Principal's Managerial in Improving the Quality of Education in Primary School. Journal of Social Work and Science Education, 2(1), 52-59. https://doi.org/10.52690/jswse.v2i1.205

Pranowo. (2014). Teori Belajar Bahasa untuk Guru dan Mahasiswa Jurusan Bahasa [Language Learning Theory for Language Department Teachers and Students]. Yogyakarta: Pustaka Pelajar.

Pujaastawa, I, B. (2016). Teknik Wawancara Dan Observasi Untuk Pengumpulan Bahan Informasi [Interview and Observation Techniques for Collecting Information Materials]. Fakultas Studi Antrophologi,Universitas Udayana.

Regulation of the Minister of Education and Culture No. 22 of 2016

Regulation of the Minister of Education and Culture No. 65 of 2013 
Journal of Social Work and Science Education

Volume 3 (1) 2022

E-ISSN: 2723-6919 P-ISSN: 2746-0827

Sani, R. (2014). Pembelajaran Saintifik Untuk Kurikulum 2013 [Scientific Learning For Curriculum 2013]. Jakarta: Bumi Aksara.

Sanjaya, A. (2018). Model-Model Pembelajaran [Learning Models]. Jakarta: Bumi Aksara.

Setyosari, P. (2020). Desain Pembelajaran [Learning Design]. Jakarta: Bumi Aksara.

Sugiyono. (2015). Metode Penelitian Kuantitatif, Kualitatif dan R\&D [Quantitative, Qualitative and R\&D Research Methods]. Bandung: Alfabeta 